\title{
Effect of Principal Management and Teacher's Learning Media on Student Learning Achievement
}

\author{
Santi $^{\left.1^{*}\right)}$, Nur Ahyani ${ }^{2}$, Syaiful Eddy ${ }^{2}$ \\ ${ }^{I}$ SD Negeri Meka Jaya \\ ${ }^{2}$ Universitas PGRI Palembang \\ "Corresponding author.Email: jaya180885santi@gmail.com
}

\begin{abstract}
The goals of this paper were to know: 1) the influence of principal management on learning achievement, 2) the influence and impact of media to the learning achievement, 3) work environment and motivation on teacher job satisfaction. This study used quantitative methods. Data were processed using multiple linear regressions using the SPSS program for Windows Version 26. The results show that: 1) there is an impact and influence of the principal management on achievement of the student;2) effect of learning media on student learning achievement was observed, and 3) There is an influence between principal management and teacher learning media together on student learning achievement. In addition, this study can be used to improve the student's learning achievement in future.
\end{abstract}

Keywords: Principal management, Teacher learning media, Student learning achievement.

\section{INTRODUCTION}

The school headmaster or principal is one of the main components of education that has the most roles in improving the quality of education. In the context of regional autonomy and education decentralization, the process of developing human resources should touch various areas of education that must be reflected to the personal and leader, including educational leaders, such as school principals. In line with the opinion of [1] that in its implementation in schools, this goal can be played by the principal in managing education, both in planning, organizing, implementing, supervising, and controlling education in schools. Principals are required to be able to develop various potentials and abilities in the aspect of leadership in managing school resources according to their abilities and needs.

The duties and functions of the principal are of course not a few, one of which is as a motivator, which we mean here as a driving force, namely how the principal can encourage or mobilize his subordinates to educators and education personnel in fulfilling tasks. Of course, these tasks can be completed on time and carried out as much as possible in order to achieve a mutual success, namely success in carrying out the vision and mission of the school that has been mutually agreed upon. In line with the opinion of [2] that teachers are human resource who fill positions and play an important role in education. When everyone raises questions about the world of education, the teacher figure must be involved in the discussion agenda, especially those concerning formal education in schools.

The teacher as a presenter of compulsory learning materials and must pay attention to individual aspects of students as subjects receiving learning material. Teachers have to be excellence in choosing learning methods and media in order to be in accordance with the conditions of students' abilities in the classroom. In line with the opinion of [3] that the use of the media of learning is one of the factors inhibiting the process of applying managerial principals in improving teacher competence as a teacher who does not dominate media learning undoubtedly learning objectives to be achieved will not be performing well.

Based on the observations of pre-research activities at SD Negeri Jirak Jaya District, it is seen from the low student achievement as indicated by the daily and semester test scores which is still below the Minimum Completeness Criteria; this proves that the principal and teachers are less enthusiastic. Changes in terms of improving learning sufficiently complete facilities and infrastructure, adequate learning planning, media and learning methods that are not suitable for children's abilities. In addition, there are less close cooperative relationships between existing fields, 
less harmonious relationships between individuals, many teachers / employees who do not understand the details of tasks, teach without preparing teaching tools, lack of coaching in various lines, and work discipline is not enforced, such as: leaving prematurely, inaccurate in carrying out assignments, delaying assigned assignments, often leaving school or even not coming to work without clear reasons. As a result, the situation in the elementary school (SD) was not running effectively.

Based on the above background, the writer will examine this problem by conducting a study entitled "Effect of Principal Management and Teacher's Learning Media on Student Learning Achievement", with these efforts expected to improve and improve teacher quality, procurement of books and instructional media, improvement of facilities and infrastructure, increased leadership and school management.

\section{METHODS}

The research was ex post facto research, which refers to the treatment or manipulation of the independent variable that has occurred before, it remains only to see the effect on the dependent variable. In terms of its objectives, this study is a causal comparative study. The research method of comparative causal analysis was chosen because it will study the relationship between two or more variables, namely the relationship between variations in one consensus and variations in another.

The research was conducted at 17 SD Negeri Jirak Jaya Subdistrict as many as 50 teachers as a sample of a population of 158 teachers using an instrument in the form of a questionnaire or ioner questionnaire to measure the variables of principal management and teacher. Before the research was carried out, the instrument was tested in the form of a questionnaire or questionnaire which will be filled in by 20 teachers who each of the 3 schools as the research site. The data analysis technique was carried out with the help of the SPSS program.

\section{RESULTS AND DISCUSSION}

\section{The Impact of Principal Management on Student Learning Achievement}

The results showed that the Principal Management (X1) to Student Achievement (Y) after analysis of data obtained by value $\mathrm{t}_{\text {arithmetic }}(6.641)>\mathrm{t}$ table (2.011) at the significant level of $5 \%$ and a probability value (p) of $0.000<0,05$. From these results, we concluded that there is a significant impact of Principal Management (X1) on Student Achievement (Y) SD Negeri in Jirak Jaya District. From this statement it can be said that Ho is rejected and $\mathrm{Ha}$ is accepted. In addition, it also explains the percentage of the influence of Principal
Management (X1) on Student Learning Achievement (Y) which is called the coefficient of determination which is the result of squaring R. From the table above, it is obtained the coefficient of determination (Adjusted $R$ Square) of 0.764 which contains the meaning that the effect of Principal Management (X1) on Student Learning Achievement (Y) was 76.4\%; while the remaining $23.6 \%$ was affected by other factors not studied in this research.

Principal management is an act of carrying out its duties and functions in an organization owned by the leadership [4]. The leader referred to in this research is the principal as a leader who regulates and leads in an educational institution or school. Leadership is the beginning of a new structure or procedure to achieve organizational goals and objectives or to change organizational goals and objectives [5].

The results of this research are in line with the findings of research by [6]. The results of this study indicate that: 1) There is an effect of the principal's managerial ability (X1) on student achievement (Y) in SMA in Tanjung Raja sub-district, 2) there is an effect of the use of instructional media by teachers (X2) on student achievement (Y) in SMA in Tanjung Raja subdistrict, 3) There is a significant influence between the managerial ability of the principal (X1), and the use of learning media by the teacher (X2) on student achievement $(\mathrm{Y})$. The implications of this research are: 1) The principal is an educational leader in the education unit level who is fully responsible for the quality of education and also the progress and decline of the school he leads. the principal is also a figure who must be a role model for all in the school environment; 2) The practice of learning media by the teacher makes the learning process more enjoyable, increases stimulation and motivation of learning activities, and even affects students psychologically.

\section{The Impact of Teacher Learning Media on Student Learning Achievement}

We found that the Teacher Learning Media (X2) on Student Learning Achievement (Y) after data analysis obtained the value of $t_{\text {count }}(6.015)>t$ table (2.011) at the significant level of $5 \%$ and the probability value $(\mathrm{p})$ of $0.000<0,05$. From these results it can be concluded that there is a significant effect of Teacher Learning Media (X2) on Student Achievement (Y) SD Negeri in Jirak Jaya District. From this statement it can be said that Ho is rejected and $\mathrm{Ha}$ is accepted. In addition, it also explains the percentage of influence of Teacher Learning Media (X2) on Student Learning Achievement (Y) which is called the coefficient of determination which is the result of squaring R.From the table above, it is obtained the coefficient of determination ( Adjust $R$ Square) of 0.418 which contains the meaning that the 
effect of Teacher Learning Media (X2) on Student Learning Achievement (Y) is $41.8 \%$; while the remaining $58.2 \%$ is influenced by other variables not examined in this study.

The results showed that the Teacher Learning Media (X2) on Student Learning Achievement (Y) after data analysis obtained the value of $t$ count (6.015)> $t_{\text {table }}(2.011)$ at the significant level of $5 \%$ and the probability value $(\mathrm{p})$ of $0.000<0,05$. From these results it can be concluded that there is a significant effect of Teacher Learning Media (X2) on Student Achievement (Y) SD Negeri in Jirak Jaya District. From this statement it can be said that $\mathrm{Ho}$ is rejected and $\mathrm{Ha}$ is accepted. In addition, it also explains the percentage of influence of Teacher Learning Media (X2) on Student Learning Achievement (Y) which is called the coefficient of determination which is the result of squaring R.From the table above, it is obtained the coefficient of determination ( Adjust $R$ Square ) of 0.418 which contains the meaning that the effect of Teacher Learning Media (X2) on Student Learning Achievement $(\mathrm{Y})$ is $41.8 \%$; while the remaining $58.2 \%$ is influenced by other variables not examined in this study.

According to Arsyad [7], learning media is an intermediary or messenger for messages from message senders to message recipients. Learning media is an intermediary that can be used to transmit messages from sender to message recipient. Furthermore, according to Sanaky [8] that learning media is a tool that functions and can be used to convey learning messages. Learning media is a tool that functions to convey learning content or messages. Sadiman [9] concurs that learning media are anything that can be used to transmit messages from the sender of the message to the recipient, so that it can stimulate thoughts, feelings, attention, and student interests in such a way that the learning process occurs. Learning media is anything that can be used to transmit messages, stimulate students' thoughts, feelings, attention and willingness, so that it will encourage students to be involved in learning activities. [10]

\section{The Effect of Principal Management and Teacher Learning Media on Student Learning Achievement}

The results showed that the Principal Management (X1) and Teacher Learning Media (X2) on Student Learning Achievement (Y) after the data analysis was carried out the $F$ value calculated $(11.295)>F_{\text {table }}(3.19)$ with a significance value of $0.000<0,05$. Thus, the results of hypothesis 3 test can be concluded that there is a simultaneous significant effect of Principal Management (X1) and Teacher Learning Media (X2) on Student Learning Achievement (Y). In addition, it also explains the percentage of influence of the independent variables (Principal Management and Teacher Learning
Media) on the dependent variable (Student Learning Achievement) which is called the coefficient of determination which is the result of squaring R.From the table above, the coefficient of determination (Adjust $R$ Square) of 0.823 which implies that the influence of the independent variables (Principal Management and Teacher Learning Media) on the dependent variable (Student Learning Achievement) is $82.3 \%$; while the remaining $17.7 \%$ is influenced by other variables not examined in this study.

The results showed that the Principal Management (X1) and Teacher Learning Media (X2) on Student Learning Achievement (Y) after the data analysis was carried out the $F$ value calculated $(11.295)>F_{\text {table }}(3.19)$ with a significance value of $0.000<0,05$. Thus, the results of hypothesis 3 test can be concluded that there is a simultaneous significant effect of Principal Management (X1) and Teacher Learning Media (X2) on Student Learning Achievement (Y). In addition, it also explains the percentage of influence of the independent variables (Principal Management and Teacher Learning Media) on the dependent variable (Student Learning Achievement) which is called the coefficient of determination which is the result of squaring R.From the table above, the coefficient of determination (Adjust $R$ Square) of 0.823 which implies that the influence of the independent variables (Principal Management and Teacher Learning Media) on the dependent variable (Student Learning Achievement) is $82.3 \%$; while the remaining $17.7 \%$ is influenced by other variables not examined in this study.

The findings of this study are in line with the results of research by Fitria [11]. The results of this study indicate that: 1) the optimal form of leadership is played by the principal in the role of a leader, manager and motivator; 2) The obstacle faced by the principal when carrying out his duties is that the performance of the honorary work at this school has been running quite well even though some of them still lack discipline in their attendance for various reasons and interests.

\section{CONCLUSION}

In summary, we concluded that: 1) there is an impact and influence of the Principal Management on Student Learning Achievement; 2) there is an effect of Teacher Learning Media on Student Learning Achievement; and 3) there is an effect of Teacher Learning Media on Student Learning Achievement.

\section{REFERENCES}

[1] Ahyani, N, Juniarti, E., \& Ardiansyah, A. (2020). Pengaruh Kepemimpinan Kepala Sekolah dan Disiplin Guru terhadap Kinerja Guru. Journal of Education Research, 1(3), 2020, Pages 193-199. 
[2] Eddy, S, Dahlan, M., \& Arafat, Y. (2020). Pengaruh Budaya Sekolah dan Diklat terhadap Kinerja Guru. Journal of Education Research, 1(3), 2020, Pages 218-225.

[3] Eddy, S, Marce, S., \& Ahmad, S. (2020). Manajemen Kepemimpinan Kepala Sekolah Sebagai Administrator Dalam Peningkatan Kompetensi Guru. Dawuh Islamic Education Jurnal, Vol. 1, No. 2, Juli 2020.

[4] Wahjosumijo. (2017). Kepemimpinan Kepala Sekolah. Jakarta: Raja Grafindo Persada.

[5] Purwanto. (2016). Evaluasi Hasil Belajar. Yogyakarta: Pustaka Pelajar.

[6] Tristiniar., Harapan, E. \& Destiniar. (2020). Pengaruh Kemampuan Manajerial Kepala Sekolah dan Penggunaan Media Pembelajaran oleh Guru terhadap Prestasi Belajar Siswa. Jurnal Ilmiah Adminstrasi, Manajemen dan Kepemimpinan Pendidikan. ISSN: 1978-1938 (Print) 2580-6491. Volume 2 Number 1, 22-42. April 2020. Hal. 2242 .
[7] Arsyad, A. (2016). Media Pembelajaran. Jakarta: Rajawali Pers.

[8] Sanaky, A.H. (2013). Media Pembelajaran Interaktif-Inovatif. Yogyakarta: Kaukaban Dipantara.

[9] Sadiman, Arief, S. (2016). Media Pendidikan: Pengertian, Pengembangan dan Pemanfaatannya. Jakarta: PT. Raja Grafindo Persada.

[10] Tri Yulianti. (2018). Pengaruh Penggunaan Media Pembelajaran Terhadap Hasil Belajar Siswa Pada Mata Pelajaran Ekonomi di SMA. Jurnal Ilmiah Pendidikan. ISSN: 0867-0827. Volume 3 Number 2, Mei 2018. Hal. 78-80.

[11] Fitria, Fitria, H., \& Martha, M. (2020). Manajemen Kepemimpinan Kepala Sekolah dalam Meningkatkan Kinerja Guru Honorer. Journal of Innovation in Teaching and Instructional Media, Vol. 1 No. 1, September 2020 Page 85-89. 